\title{
Effects of dietary protein and essential amino acid deficiencies on growth, body composition, and digestive enzyme activities of silvery-black porgy (Sparidentex hasta)
}

\author{
Mansour Torfi Mozanzadeh $(\mathbb{D} \cdot$ Morteza Yaghoubi · Jasem G. Marammazi • \\ Omid Safari • Enric Gisbert
}

Received: 31 May 2017/ Accepted: 29 December 2017/Published online: 30 January 2018

(C) The Author(s) 2018. This article is an open access publication

\begin{abstract}
A 6-week feeding trial was conducted to evaluate the effects of protein-free (PF) and essential amino-acid-deficient (EAAD) diets on the growth performance and digestive enzyme activities of silveryblack porgy (Sparidentex hasta) juveniles. Three experimental diets were formulated: a control diet in which $60 \%$ of dietary nitrogen was provided by intact protein (fish meal) and $40 \%$ by crystalline AA [(blends of essential amino acids (EAA) and none essential amino acids (NEAA)]; an essential amino-acid-deficient diet in which $60 \%$ of dietary $N$ was provided by intact protein, whereas the rest was provided by NEAA and a protein-free (PF) diet, based on carbohydrate sources. Survival rates in fish fed the EAAD and PF diets were lower than in fish fed the control diet. Weight gain in fish fed with EAAD was $5.6 \mathrm{~g}$ lower than fish fed with the control diet. Furthermore, fish fed the PF diet lost weight and their final body weight was $12.2 \mathrm{~g}$ lower than the control group. Fish fed the PF diet had the highest whole-body moisture, but the lowest whole-body protein, lipid, threonine, aspartic acid, glutamic acid, and serine levels. Digestive pancreatic enzyme activities including trypsin, lipase, $\alpha$-amylase, and carboxypeptidase A significantly decreased in fish fed EAAD and PF diets. The information obtained from this study testing two extreme diets (EAAD and PF) may serve for better understanding the impact of protein and EAA nutritional imbalances in fish performance.
\end{abstract}

Keywords Amino acid profile $\cdot$ Feed efficiency $\cdot$ Nitrogen retention $\cdot$ Sparidae $\cdot$ Digestive enzymes

\section{Introduction}

The optimization of the dietary protein and essential amino acid (EAA) profile according to the requirements of a given fish species maximizes dietary EAA and non-EAA utilization and increases protein synthesis resulting in a proper fish growth and economic return. An absolute requirement for the 10 EAA (arginine,

M. T. Mozanzadeh $(\bowtie) \cdot$ M. Yaghoubi · J. G. Marammazi

Agriculture Research, Education and Extension, Iran Fisheries Research Organization (IFRO), South Iran Aquaculture

Research Center, Ahwaz, Iran

e-mail: mansour.torfi@gmail.com

O. Safari

Department of Fisheries, Faculty of Natural Resources and Environment, Ferdowsi University of Mashhad, Khorasan Razavi, Iran

E. Gisbert

Unitat de Cultius Experimentals, Centre de Sant Carles de la Rápita (IRTA-SCR), IRTA, Crta. del Poble Nou Km 5.5,

Sant Carles de la Rápita, Spain 
histidine, isoleucine, leucine, lysine, methionine, phenylalanine, threonine, tryptophan, and valine) has been demonstrated in most fish species studied to date (NRC 2011). Essential amino acids are key molecules for building proteins, as well as important regulators of key metabolic pathways including cell signaling, appetite stimulation, growth and development, energy utilization, immunity, osmoregulation, ammonia detoxification, antioxidative defense, metamorphosis, pigmentation, gut and neuronal development, stress responses, reproduction, and suppression of aggressive behavior in aquatic animals (Wu et al. 2013, 2014). In addition, the previous studies have reported that different EAA have a significant role on the digestive enzyme activities in fish (Tang et al. 2009, 2013, Chen et al. 2012, Li et al. 2015). In fact, the positive effects of dietary EAA supplementation on the activities of digestive enzymes may partially be attributed to the growth and structural integrity of pancreas and intestinal brush borders as it has been reported in the above-mentioned studies.

Silvery-black porgy (Sparidentex hasta) is recognized as one of the most promising fish species for aquaculture diversification in the Persian Gulf and the Oman Sea regions. In this regard, during recent years, nutritional studies focused on establishing the nutritional requirements for improving diet formulation for this species (Mozanzadeh et al. 2017). Previous studies have shown that the dietary protein requirement of $S$. hasta juvenile is estimated to be $48 \%$, being fish meal the major source of protein in the diet (Mozanzadeh et al. 2017). Moreover, the optimal dietary EAA profile for $S$. hasta juveniles was estimated to be $(\mathrm{g} 16 \mathrm{~g} / \mathrm{N})$ : arginine 5.3, lysine 6.0, threonine 5.2, histidine 2.5, isoleucine 4.6, leucine 5.4, methionine + cysteine 4.0 (in a diet containing 0.6 cysteine), phenylalanine + tyrosine 5.6 (in a diet containing 1.9 tyrosine), tryptophan 1.0, and valine 4.6 (Marammazi et al. 2017). In addition, Yaghoubi et al. (2017) reported that arginine, threonine, and lysine were the most limited EAA for humoral immunity in this species. Several studies used protein-free diets (PF) for estimating nitrogen utilization and loss as well as protein and EAA requirements for maintenance in different fish species (Kaushik et al. 1995, Abboudi et al. 2006, 2009). To our knowledge, there is no available information about the effects of dietary protein and EAA deficiencies on physiological responses in this sparid species. Thus, the present study aimed to evaluate effects of protein and EAA deficiencies on the growth performance, feed utilization, body composition, and pancreatic digestive enzyme activities to clarify how protein and EAA deficiencies can affect physiological responses in this species.

\section{Materials and methods}

Experimental diets

Three diets were formulated (Tables 1,2): a control diet (74.7 g N/kg DM), a diet deficient in essential amino acids (EAAD $76.6 \mathrm{~g} \mathrm{~N} / \mathrm{kg} \mathrm{DM}$ ), and a protein-free diet (PF $7.5 \mathrm{~g} \mathrm{~N} / \mathrm{kg} \mathrm{DM}$ ). In the control diet, $60 \%$ of dietary $\mathrm{N}$ was provided by intact protein (fishmeal and gelatine) and $40 \%$ by crystalline AAs (CAA). The CAA mixture was prepared by a blend of EAA and non-essential amino acids (NEAA), which were coated with $1 \%$ agar in order to delay their absorption and to optimize their use for protein accretion (Peres and Oliva-Teles 2006). All the EAA and NEAA incorporated in the CAA mixture of the control diet simulated the AA profile of FM from Clupeonella sp. and matched the EAA nutritional requirements for this species (Marammazi et al. 2017). Agar was dissolved in boiled water $\left(10 \mathrm{~g} / \mathrm{kg}\right.$ of the diet) and cooled to $40{ }^{\circ} \mathrm{C}$ before the addition of CAAs (Peres and Oliva-Teles 2006). Regarding the EAAD diet, $60 \%$ of dietary $N$ was provided by fish meal, whereas the rest was incorporated as a mixture of NEAA (crystalline form). The PF diet was based on wheat middling, corn starch, and fish oil. In all diets, ingredients were finely ground (particle size: $<500 \mu \mathrm{m}$ ), mixed together in a Hobart mixer, and then, the pre-coated CAA mixture was added, followed by the fish oil and sufficient distilled water to form a soft dough that was extruded to obtain pellets of $2 \mathrm{~mm}$ in size. Pellets were dried in a convection oven at $25{ }^{\circ} \mathrm{C}$ and stored in re-sealable plastic bags at $-20{ }^{\circ} \mathrm{C}$ until their use.

Feeding trial

Experimental procedures were conducted in compliance with the guidelines of the international council for laboratory animals science for the use of laboratory animals. The study was carried out at the Mariculture Research Station of the South Iranian Aquaculture Research Center (SIARC) (Khuzestan, Sarbandar, Iran). 
Table 1 Ingredient and proximate composition of the control, essential amino-acid-deficient (EAAD), and protein-free (PF) diets

\begin{tabular}{|c|c|c|c|}
\hline & \multicolumn{3}{|l|}{ Diets } \\
\hline & Control & EAAD & $\mathrm{PF}$ \\
\hline \multicolumn{4}{|c|}{ Dietary ingredients ( $\mathrm{g} \mathrm{kg}^{-1}$ dry diet) } \\
\hline Fish meal $^{\mathrm{a}}$ & 360 & 360 & - \\
\hline Gelatin $^{\mathrm{b}}$ & 40 & 40 & - \\
\hline Wheat middling $^{\mathrm{c}}$ & 70 & 70 & 275 \\
\hline Corn $\operatorname{starch}^{\mathrm{d}}$ & 205 & 205 & 540 \\
\hline Fish oil ${ }^{\mathrm{e}}$ & 110 & 110 & 155 \\
\hline $\operatorname{Agar}^{\mathrm{f}}$ & 10 & 10 & 10 \\
\hline Vitamin Premix ${ }^{\mathrm{g}}$ & 10 & 10 & 10 \\
\hline Mineral Premix ${ }^{\mathrm{h}}$ & 10 & 10 & 10 \\
\hline L-arginine & 8.5 & - & - \\
\hline L-lysine- $\mathrm{HCl}$ & 11.5 & - & - \\
\hline L-threonine & 8 & - & - \\
\hline L-histidine & 5 & - & - \\
\hline L-isoleucine & 8.5 & - & - \\
\hline L-leucine & 14 & - & - \\
\hline L-methionine & 6 & - & - \\
\hline L-phenylalanine & 7.5 & - & - \\
\hline L-tryptophan & 2 & - & - \\
\hline L-valine & 9.5 & - & - \\
\hline NEAA mixture ${ }^{\mathrm{i}}$ & 104.5 & 185 & - \\
\hline \multicolumn{4}{|l|}{ Proximate composition (\%) } \\
\hline Dry matter & $92.9 \pm 0.4$ & $93.2 \pm 0.1$ & $91.5 \pm 0.3$ \\
\hline Crude protein & $46.7 \pm 0.6$ & $47.9 \pm 0.1$ & $4.7 \pm 2.5$ \\
\hline Crude lipid & $20.1 \pm 0.0$ & $20.0 \pm 0.0$ & $19.9 \pm 0.6$ \\
\hline $\mathrm{NFE}^{\mathrm{j}}$ & $19.1 \pm 0.5$ & $18.3 \pm 0.2$ & $64.3 \pm 1.7$ \\
\hline Ash & $6.8 \pm 0.1$ & $6.1 \pm 0.1$ & $1.6 \pm 0.0$ \\
\hline Gross energy $\left(\mathrm{kJ} \mathrm{g}^{-1}\right)^{\mathrm{k}}$ & $20.9 \pm 0.1$ & $20.1 \pm 0.0$ & $19.5 \pm 0.0$ \\
\hline
\end{tabular}

${ }^{\mathrm{a}}$ Fish meal (Clupeonella sp.); Parskilka Mazandaran, Iran (63.5\% crude protein, $17.7 \%$ crude lipid)

${ }^{\mathrm{b}}$ Gelatine; Beyza feed mill, Shiraz, Iran. (85\% crude protein, crude lipid, 4.2)

${ }^{\mathrm{c}}$ Wheat meal; Beyza feed mill, Shiraz, Iran. 12\% crude protein, 3\% crude lipid)]

${ }^{\mathrm{d}}$ Corn starch, Beyza feed mill, Shiraz, Iran

eParskilka Mazandaran, Iran (Clupeonella sp.)

${ }^{\mathrm{f}}$ Merck, Germany

${ }^{\mathrm{g}}$ Vitamin premix $\left(\mathrm{mg} \mathrm{kg}^{-1}\right)$ of premix: vitamin A, 5,000,000 IU; vitamin D3, 500,000 IU; vitamin E, $3000 \mathrm{mg}$; vitamin $\mathrm{K} 3$, 1500; vitamin B1, 6000; vitamin B2, 24,000; vitamin B5, 52,000; vitamin B6, 18,000; vitamin B12, 60,000; folic acid, 3000; nicotinamide 180,000; antioxidant, 500, Damloran pharmaceutical company, Broujerd, Iran

${ }^{\mathrm{h}}$ Mineral premix $\left(\mathrm{mg} \mathrm{kg}^{-1}\right.$ ) of premix: copper, 3000; zinc, 15,000; manganese, 20,000; Iron, 10,000; potassium iodate, 300. Microvit $^{\circledR}$, Razak laboratories, Tehran, Iran

Crystalline amino acids: Merck, Germany, except isoleucine (Sigma-Aldrich, USA)

${ }^{\mathrm{i} D}$ Dispensable amino acid mixture (\% mixture): L-alanine: 13; L-aspartic acid: 20; sodium glutamate: 32; L-glycine: 15; L-serine: 10; and L-proline: 10, Merck, Germany

${ }^{\mathrm{j}}$ Nitrogen-free extract $=100-($ protein + lipid + ash $)$

${ }^{\mathrm{k}}$ Gross energy content was estimated as: total carbohydrate $\times 17.2 \mathrm{~J} \mathrm{~kg}^{-1}$; fat $\times 39.5 \mathrm{Jkg}^{-1}$; and protein $\times 23.5 \mathrm{~J} \mathrm{~kg}^{-1}$

Fish were adapted to the experimental conditions for 2 weeks and fed with the control diet during this period. 135 juveniles [initial body weight $\left(\mathrm{BW}_{\mathrm{i}}\right)$ of $4.7 \pm 0.1 \mathrm{~g}$; mean \pm standard error] were randomly distributed into 9 cylindrical polyethylene tanks ( 2501 of volume; 15 fish/tank; 3 replicates per diet). Fish were hand fed each of the experimental diets to visual satiation, three times per day $(0800,1200$, and $1600 \mathrm{~h})$, for 42 days. 
Table 2 Amino acid profile of the control, essential amino acid deficient (EAAD), and protein-free (PF) diets $(n=1), \mathrm{g}^{100 \mathrm{~g}^{-1}}$ Diet

\begin{tabular}{llll}
\hline Amino acid composition & Control & EAAD & PF \\
\hline Arginine & 2.6 & 1.7 & 0.2 \\
Lysine & 2.2 & 1.3 & 0.2 \\
Threonine & 1.9 & 1.9 & 0.2 \\
Histidine & 1.2 & 0.7 & 0.1 \\
Isoleucine & 2.1 & 1.2 & 0.3 \\
Leucine & 2.4 & 1.5 & 0.3 \\
Methionine & 1.4 & 0.8 & 0.1 \\
Cysteine* & 0.3 & 0.3 & 0.1 \\
Phenylalanine & 1.8 & 1.1 & 0.3 \\
Tyrosine & 0.9 & 0.9 & 0.2 \\
Tryptophan* & 0.5 & 0.3 & 0.1 \\
Valine & 2.1 & 1.3 & 0.3 \\
Alanine & 3.6 & 4.4 & 0.2 \\
Aspartate & 5.5 & 6.7 & 0.3 \\
Glutamate & 7.8 & 9.8 & 0.3 \\
Glycine & 5.0 & 6.0 & 0.3 \\
Proline & 2.3 & 3.0 & 0.2 \\
Serine & 2.0 & 2.7 & 0.3 \\
\hline
\end{tabular}

*These amounts were calculated based on the ingredient cysteine and tryptophan composition

Uneaten pellets were drained off an hour after feeding and counted every day to calculate the total feed intake (FI) per tank using a mean dry pellet weight. Tanks were supplied with filtered seawater (flow rate $1 \mathrm{l} / \mathrm{min}$; salinity $48.0 \pm 0.5 \%$; oxygen $7.6 \pm 0.2 \mathrm{mg} / \mathrm{l} ; \mathrm{pH} 7.8 \pm 0.4$; temperature of $29.0 \pm 1.5^{\circ} \mathrm{C}$ ) and subjected to natural photoperiod $\left(30^{\circ} 32^{\prime} \mathrm{N}, 49^{\circ} 20^{\prime} \mathrm{E}\right.$; June and July).

Sample collection

At the end of the trial, fish were fasted for $24 \mathrm{~h}$ before being anaesthetized (2-phenoxyethanol at $0.5 \mathrm{ml} / \mathrm{l}$; Merck, Schuchardt, Germany) and individually weighed $\left(\mathrm{BW}_{\mathrm{f}}\right)$. For blood collection, three specimens from each replicate $\operatorname{tank}(n=9$ per diet, $n=3$ per experimental replicate) were anesthetized and blood (ca. $250-500 \mu \mathrm{l})$ was collected from the caudal vein with heparinized syringes, then centrifuged $\left(4000 \times g, 10 \mathrm{~min}, 4{ }^{\circ} \mathrm{C}\right)$ and plasma separated. The vials containing plasma samples were transferred into liquid nitrogen and stored at $-80{ }^{\circ} \mathrm{C}$ until further analysis. For the assessment of digestive enzyme activities, three fish per $\operatorname{tank}(n=9$ fish per diet treatment, $n=3$ fish per replicate) were randomly sampled, euthanized with the same anaesthetic, and immediately eviscerated on ice surface. The alimentary tract was dissected, adherent adipose and connective tissues carefully removed and placed in individually marked plastic test tubes and stored at $-80^{\circ} \mathrm{C}$ until their analysis. For whole-body biochemical analyses, at the beginning of the trial, five fish from the initial stock were killed with an overdose of the anaesthetic and frozen at $-80{ }^{\circ} \mathrm{C}$ for subsequent analysis. At the end of the feeding trial, three fish per experimental replicate were sacrificed with overdose of the same anaesthetic for subsequent biochemical analyses.

Fish growth, condition, and feed efficiency parameters

The $\mathrm{BW}_{\mathrm{f}}$, liver, viscera, and intraperitoneal fat weights were measured to the nearest $0.1 \mathrm{~g}$ and standard length (SL) to the nearest $1 \mathrm{~mm}$. The following formulae were used to assess growth performance, feed utilization, and other parameters: body weight gain $(\mathrm{WG}, \mathrm{g})=\left(\mathrm{BW}_{\mathrm{f}}-\mathrm{BW}_{\mathrm{i}}\right)$; specific growth rate $(\mathrm{SGR}, \% /$ day $)=[(\ln$ $\left.\left.\mathrm{BW}_{\mathrm{f}}-\ln \mathrm{BW}_{\mathrm{i}}\right) / t\right] \times 100$, where $t$ is experimental period (42 days); survival rate $(\mathrm{SR}, \%)=$ (number of fish in each group remaining on day 42 /initial number of fish) $\times 100$; feed intake $(\mathrm{FI})=$ total feed intake $(\mathrm{g}) /$ number of fish; feed conversion ratio $(\mathrm{FCR}, \%)=($ feed intake $(\mathrm{g}) /$ weight gain $(\mathrm{g})$ ); protein efficiency ratio 
$($ PER $)=$ weight gain $(\mathrm{g}) /$ protein intake $(\mathrm{g})$; condition factor $(K)=($ body weight $(\mathrm{g}) /($ body length $\left.(\mathrm{cm}))^{3}\right) \times 100$; hepatosomatic index $($ HSI, \%) $=($ liver weight $(\mathrm{g}) /$ whole-body weight $(\mathrm{g})) \times 100$; viscerosomatic index $(\mathrm{VSI}, \%)=($ visceral weight $(\mathrm{g}) /$ whole-body weight $(\mathrm{g}))$ and intraperitoneal fat index (IPF, $\%)=(\operatorname{IPF}$ weight $(\mathrm{g}) /$ whole-body weight $(\mathrm{g})) \times 100$. Daily $N$ intake, gain and retention were estimated by following formulas:

$$
\begin{aligned}
& \text { Mean metabolic weight gain }(\mathrm{MBW})=0.5 \times\left(\mathrm{BW}_{f}^{0.75}+\mathrm{BW}_{i}^{0.75}\right), \\
& N \text { intake }(\mathrm{g} \mathrm{N} / \mathrm{kg} \mathrm{MBW} / \text { day })=\left(D_{i} \times N_{d}\right) /(\mathrm{MBW} \times t), \\
& N \text { gain }(\mathrm{g} \mathrm{N} / \mathrm{kg} \mathrm{MBW} / \text { day })=\left(\mathrm{BW}_{f} \times N_{f}-\mathrm{BW}_{i} \times N_{i}\right) /(\mathrm{MBW} \times t), \\
& N \text { retention }(\% N \text { intake })=(N \text { gain } / N \text { intake }) \times 100
\end{aligned}
$$

where MBW is the average metabolic body weight; $D_{i}$ is the dry feed intake $(\mathrm{g}) ; N_{\mathrm{d}}$ is the $N$ content of the experimental diets; $t$ is the duration of the feeding period (42 days), $N_{i}$ and $N_{f}$ are the initial and final body $N$ content, and $\mathrm{BW}_{i}$ and $\mathrm{BW}_{f}$ are the mean initial and final body weight, respectively.

Biochemical analyses

Proximate analyses of ingredients, diets and whole body were determined using the standard methods (AOAC 2005). Amino acids (except for tryptophan and cysteine because of the susceptibility of these AA to acid hydrolysis) were determined after hydrolysis. Samples were hydrolysed in $6 \mathrm{~N} \mathrm{HCl}$ for $24 \mathrm{~h}$ at $110{ }^{\circ} \mathrm{C}$ in glass vials filled with nitrogen. O-phthalaldehyde (OPA) was used as a pre-column derivatization reagent according to Lindroth and Mopper (1979). Total AA levels were determined by HPLC (Knauer, Germany), using C18 column (Knauer, Germany), at a flow rate of $1 \mathrm{ml} / \mathrm{min}$ with fluorescence detector (RF-530, Knauer, Germany). Peak identification and integration was performed by the software Waters Empower 2 (Milford, MA) using an AA standard $\mathrm{H}$ (Pierce, USA) as an external standard. Plasma biochemical parameters including glucose, total protein, albumin, and creatinine were analyzed by means of an auto-analyser (Mindray BS-200, China) using commercial clinical investigation kits (Pars Azmoon Kit, Tehran, Iran).

Determination of digestive enzymes

Samples were homogenized in 30 volumes (w/v) of ice-cold mannitol $(50 \mathrm{mM})$, Tris-HCl buffer $(2 \mathrm{mM}) \mathrm{pH}$ 7.0, at a maximum speed for $30 \mathrm{~s}$ (IKA, Ultra-turrax ${ }^{\circledR}$, USA); then, $100 \mu 1$ of $0.1 \mathrm{M} \mathrm{CaCl}_{2}$ was added to the homogenate, which was centrifuged at $10,000 \times g$ for $10 \mathrm{~min}$ at $4{ }^{\circ} \mathrm{C}$ and the supernatants collected and stored in aliquots at $-80^{\circ} \mathrm{C}$ for further enzyme quantification (Gisbert et al. 2009). Trypsin activity was measured with $N$ - $\alpha$-benzoyl-dlarginine-p-nitroanilide (BAPNA) as substrate. BAPNA ( $1 \mathrm{mM}$ in $50 \mathrm{mM}$ Tris- $\mathrm{HCl}, \mathrm{pH}$ $8.2,20 \mathrm{mM} \mathrm{CaCl}_{2}$ ) was incubated with the enzyme extract at $37{ }^{\circ} \mathrm{C}$ and absorbance was recorded at $410 \mathrm{~nm}$ (Erlanger et al. 1961). One unit of trypsin activity corresponded to $1 \mu \mathrm{mol}$ of 4-nitroaniline liberated in $1 \mathrm{~min}$ per $\mathrm{ml}$ of extracellular enzymatic extract, based on the extinction coefficient of the substrate $(\varepsilon 410=8800 \mathrm{M} /$ $\mathrm{cm}$ ). The activity of $\alpha$-amylase was determined at $25{ }^{\circ} \mathrm{C}$ using $1 \%$ starch (Sigma-Aldrich) (diluted in a buffer at $\mathrm{pH}$ 6.9, $0.02 \mathrm{M} \mathrm{Na}_{2} \mathrm{HPO}_{4}$ and $0.006 \mathrm{M} \mathrm{NaCl}$ ) as substrate by the 3, 5-dinitrosalicylic acid method (Worthington 1991) and absorbance was recorded at $540 \mathrm{~nm}$. The $\alpha$-amylase activity (U) was expressed as $\mu \mathrm{g}$ maltose liberated from starch per mg protein in sample per hour. Non-specific lipase activity was determined at $25{ }^{\circ} \mathrm{C}$ (absorbance: $405 \mathrm{~nm}$ ) using $0.4 \mathrm{mM}$ 4-nitrophenyl-myristate (Sigma-Aldrich) as substrate and absorbance were recorded at $405 \mathrm{~nm}$ (Gawlicka et al. 2000). One unit of lipase was defined as the amount of enzyme, which liberated one micromole of 4-nitrophenyl-myristate per minute. Carboxypeptidase A activity was measured using the protocol of Folk and Schirmer (1963) using HPA (hippuryl-L-phenylalanine) as substrate (dissolved in $25 \mathrm{mM}$ Tris- $\mathrm{HCl}, 10 \mathrm{mM} \mathrm{CaCl}_{2}$ buffer, $\mathrm{pH} 7.8$ ). One unit of enzyme activity was defined as $1 \mathrm{M}$ of hippuryl hydrolysed per minute using a coefficient of molar extinction of 0.36 at $254 \mathrm{~nm}$. The protein concentration of the enzyme extracts was determined by the Bradford method (Bradford 1976) using bovine serum albumin as a protein standard. All enzymes were analyzed following the recommendations provided by Solovyev and Gisbert (2016). 
Statistical analysis

Data were analyzed using SPSS version 15.0 (Chicago, IL, USA). All data are presented as mean \pm standard error of the mean. Equality of variances was tested with Levene's test and normality with Shapiro-Wilk's test. Arcsine transformations were conducted on all percentage data to achieve homogeneity of variance before statistical analysis. One-way analysis of variance was performed at a significance level of 0.05 following the confirmation of normality and homogeneity of variance. Tukey's test was used for multiple comparisons when statistical differences among groups were detected $(P<0.05)$.

\section{Results and discussion}

Fish growth, condition, and feed efficiency

In the present study, one interesting finding was the difference in the physiological responses between fish fed EAAD and PF diets. The information obtained from this study testing two extreme diets (EAAD and PF) may serve to better understand the impact of protein nutritional imbalances in fish performance, as well as generate reference values for a large series of physiological parameters under unsuitable nutritional conditions. Fish survival was significantly affected by experimental diets; thus, survival rates in fish fed the EAAD and PF diets were 8.9 and $25.6 \%$ lower, respectively, than in fish fed the control diet (Table 3). However, no external pathological signs were observed in fish, even in those fed the PF diet. Protein synthesis and accretion is a key component of the processes involved in growth response (Anthony et al. 2001). The lower survival rate in the PF and EAAD groups may have been related to disorders in different metabolic pathways, including (a) AA synthesis and catabolism, (b) generation of physiologically important low-molecular-weight peptides and nitrogenous substances, (c) intracellular protein turnover, (d) ammonia detoxification, (e) lipid and glucose metabolism, and (f) antioxidative reactions (Wu et al. 2014). In this study, weight gain in fish fed with EAAD was $5.6 \mathrm{~g}$ lower than fish fed with the control diet $(P<0.05)$. Furthermore, fish fed the PF diet lost weight and their final body weight was $12.2 \mathrm{~g}$ lower than the control group. Feed conversion ratio and PER values were negligible in fish fed with the PF diet, since those animals lost weight during the trial. All somatic indices, including the K, HSI, VSI, and IPF significantly decreased in fish fed the EAAD and PF diets $(P<0.05)$. In general, deficiency of most EAA in fish feeds leads to failure or loss of appetite, which results in a reduced FI and weight gain, as well as lower disease resistance (Wilson 2002). In addition, it has been reported that dietary deficiency in one or more EAAs results in the deamination of other AAs in the liver, which leads to an increased excretion of nitrogenous compounds and inefficient protein synthesis and somatic growth performance (Von der Decken and Lied 1993). In fact, imbalances in the dietary AA profile tend to lead to an increase in the oxidation of other EAAs and NEAAs present at normal levels in the feed, which results in reduced protein utilization (Rønnestad et al. 2007). In the current study, nitrogen retention extremely decreased in fish fed the EAAD and PF diets $(P<0.05)$. The $\mathrm{N}$ loss in fish fed the PF diet was $60 \mathrm{mg} / \mathrm{kg}$ MBW/day, indicating high whole-body protein breakdown in this group due to the lack of dietary AAs for protein synthesis, which impaired the turnover of tissue proteins. The highest plasma creatinine, which indicates high muscular AA catabolism for gluconeogenesis, in fish fed the PF diet also supported high wholebody AA breakdown in this group. However, fish fed the control and EAAD diets showed 240 and $60 \mathrm{mg} / \mathrm{kg}$ MBW/day $N$ accretion, respectively. In this context, Marammazi et al. (2017) reported that deletion of a single EAA did not significantly affect $N$ intake (g/kg MBW/day), whereas $N$ gain (g/kg MBW/day) significantly decreased in all fish fed the EAA-deficient diets and the degree of $N$ retention reduction was dependent upon the EAA deficiencies.

Body proximate composition and AA profile

Whole-body composition was significantly affected by different experimental diets (Table 4). As expected, fish fed the PF diet had the highest moisture, but the lowest protein, lipid, and gross energy contents $(P<0.05)$. The reduction in whole-body protein in the PF group was largely due to proteolysis, as an energy source to maintain lipid and carbohydrate utilization, and to synthesize the necessary enzymes and hormones 
Table 3 Growth, feed utilization, and biometric parameters of $S$. hasta juvenile fed control, essential amino acid deficient (EAAD), and protein-free (PF) diets (mean $\pm \mathrm{SE}, n=3$ )

\begin{tabular}{|c|c|c|c|}
\hline & \multicolumn{3}{|l|}{ Diets } \\
\hline & Control & EAAD & $\mathrm{PF}$ \\
\hline \multicolumn{4}{|l|}{ Growth performance } \\
\hline $\mathrm{BW}_{i}(\mathrm{~g})^{\mathrm{a}}$ & $4.6 \pm 0.1$ & $4.6 \pm 0.0$ & $4.6 \pm 0.0$ \\
\hline $\mathrm{BW}_{f}(\mathrm{~g})^{\mathrm{b}}$ & $12.8 \pm 0.5^{\mathrm{a}}$ & $7.2 \pm 0.3^{\mathrm{b}}$ & $4.0 \pm 0.1^{\mathrm{c}}$ \\
\hline $\mathrm{WG}(\mathrm{g})^{\mathrm{c}}$ & $8.2 \pm 0.6^{\mathrm{a}}$ & $2.6 \pm 0.1^{\mathrm{b}}$ & $-0.6 \pm 0.0^{\mathrm{c}}$ \\
\hline SGR ( $\%$ body weight day ${ }^{-1}$ ) & $2.4 \pm 0.1^{\mathrm{a}}$ & $1.0 \pm 0.1^{\mathrm{b}}$ & $-0.4 \pm 0.1^{\mathrm{c}}$ \\
\hline Survival $(\%)^{\mathrm{d}}$ & $100.0 \pm 0.0^{\mathrm{a}}$ & $91.1 \pm 3.1^{\mathrm{b}}$ & $74.4 \pm 2.2^{\mathrm{c}}$ \\
\hline FI $\left(\mathrm{g} \mathrm{fish}^{-1}\right)^{\mathrm{e}}$ & $11.4 \pm 0.2^{\mathrm{a}}$ & $8.4 \pm 0.2^{\mathrm{b}}$ & $6.9 \pm 0.1^{\mathrm{c}}$ \\
\hline $\mathrm{FCR}^{\mathrm{f}}$ & $1.4 \pm 0.1^{\mathrm{a}}$ & $3.2 \pm 0.1^{\mathrm{b}}$ & - \\
\hline $\mathrm{PER}^{\mathrm{g}}$ & $1.6 \pm 0.1^{\mathrm{a}}$ & $0.5 \pm 0.1^{\mathrm{b}}$ & - \\
\hline $\mathrm{K}^{\mathrm{h}}$ & $2.4 \pm 0.2^{\mathrm{a}}$ & $2.2 \pm 0.1^{\mathrm{b}}$ & $1.9 \pm 0.2^{\mathrm{c}}$ \\
\hline $\operatorname{HSI}(\%)^{\mathrm{i}}$ & $2.0 \pm 0.0^{\mathrm{a}}$ & $1.1 \pm 0.1^{\mathrm{b}}$ & $1.1 \pm 0.4^{\mathrm{b}}$ \\
\hline $\operatorname{VSI}(\%)^{\mathrm{j}}$ & $9.5 \pm 0.4^{\mathrm{a}}$ & $5.8 \pm 0.3^{\mathrm{b}}$ & $6.4 \pm 0.5^{\mathrm{b}}$ \\
\hline $\operatorname{IPF}(\%)^{\mathrm{k}}$ & $1.8 \pm 0.2^{\mathrm{a}}$ & $0.2 \pm 0.1^{\mathrm{b}}$ & $0.1 \pm 0.0^{\mathrm{b}}$ \\
\hline$N$ intake $\left(\mathrm{g} \mathrm{kg}^{-1} \mathrm{MBW}\right.$ day $\left.^{-1}\right)$ & $0.74 \pm 0.0^{\mathrm{a}}$ & $0.72 \pm 0.03^{\mathrm{a}}$ & $0.03 \pm 0.0^{\mathrm{b}}$ \\
\hline$N$ gain $\left(\mathrm{g} \mathrm{kg}^{-1} \mathrm{MBW} \mathrm{day}^{-1}\right)$ & $0.24 \pm 0.01^{\mathrm{a}}$ & $0.06 \pm 0.0^{\mathrm{b}}$ & $-0.06 \pm 0.0^{\mathrm{c}}$ \\
\hline$N$ retention ( $\% N$ intake) & $32.2 \pm 1.9^{\mathrm{a}}$ & $7.9 \pm 0.46^{\mathrm{b}}$ & - \\
\hline
\end{tabular}

A different superscript in the same row denotes statistically significant differences $(P<0.05)$

${ }^{\text {a }} \mathrm{BW}_{i}$ : initial body weight

${ }^{\mathrm{b}} \mathrm{BW}_{f}$ final body weight

${ }^{\mathrm{c}}$ SGR: specific growth rate $=((\ln$ final weight $-\ln$ initial weight $) / t) \times 100$, where $t$ is experimental period $=42$ days

${ }^{\mathrm{d}}$ Survival $=$ (number of fish in each group remaining on day 60/initial number of fish) $\times 100$

${ }^{\mathrm{e}}$ FI: feed intake $=$ feed intake/fish number

${ }^{\mathrm{f}}$ FCR: feed conversion ratio $=$ weight gain $(\mathrm{g}) /$ feed intake $(\mathrm{g})$

${ }^{g}$ PER: protein efficiency ratio $=$ weight gain $(\mathrm{g}) /$ protein intake $(\mathrm{g})$

${ }^{\mathrm{h}} \mathrm{K}$ : condition factor $=\left(\right.$ body weight $\left.(\mathrm{g}) /(\text { body length }(\mathrm{cm}))^{3}\right) \times 100$

${ }^{\mathrm{i}}$ HSI: hepatosomatic index $=($ liver weight $(\mathrm{g}) /$ whole-body weight $(\mathrm{g})) \times 100$

${ }^{\mathrm{j}}$ VSI: viscerosomatic index $=($ viscera weight $(\mathrm{g}) /$ whole-body weight $(\mathrm{g})) \times 100$

${ }^{\mathrm{k}}$ IPF: intraperitoneal fat $=(\operatorname{IPF}$ weight $(\mathrm{g}) /$ whole-body weight $(\mathrm{g})) \times 100$

for intermediary metabolism, as also reported in Atlantic salmon (Salmo salar) fry fed a PF diet (Abboudi et al. 2006, 2009). In addition, during protein turnover, protein breakdown and resynthesize occurs, with oxidation of part of the amino acids from the protein breakdown. Thus, proteolysis must have occurred due to a lack of AAs from the diet. As intestinal metabolism may have a profound influence on whole-body AA composition, the differences in patterns of AAs between diets and body proteins have been reported to be

Table 4 Composition of whole-body proximate (\% of wet weight) of $S$. hasta juvenile fed control, essential amino acid deficient $(\mathrm{EAAD})$, and protein-free $(\mathrm{PF})$ diets (mean $\pm \mathrm{SE}, n=3)$

\begin{tabular}{lrrrr}
\hline & \multicolumn{1}{l}{ Diets } & & \\
\cline { 2 - 5 } & \multicolumn{1}{l}{ Initial } & Control & EAAD & PF \\
\hline Moisture & $72.4 \pm 1.2$ & $69.7 \pm 0.9^{\mathrm{c}}$ & $74.3 \pm 1.2^{\mathrm{b}}$ & $79.6 \pm 0.7^{\mathrm{a}}$ \\
Crude protein & $17.6 \pm 0.6$ & $16.5 \pm 0.3^{\mathrm{a}}$ & $15.7 \pm 0.4^{\mathrm{a}}$ & $14.1 \pm 0.5^{\mathrm{b}}$ \\
Crude lipid & $5.1 \pm 0.3$ & $7.6 \pm 0.2^{\mathrm{a}}$ & $3.3 \pm 0.4^{\mathrm{b}}$ & $2.5 \pm 0.5^{\mathrm{c}}$ \\
Ash & $4.3 \pm 0.2$ & $4.7 \pm 0.2$ & $5.1 \pm 0.3$ & $5.4 \pm 0.1$ \\
Gross energy $\left(\mathrm{MJ} \mathrm{kg}^{-1}\right)$ & $6.2 \pm 0.2$ & $7.0 \pm 0.0^{\mathrm{a}}$ & $5.2 \pm 0.1^{\mathrm{b}}$ & $3.9 \pm 0.0^{\mathrm{c}}$ \\
\hline
\end{tabular}

A different superscript in the same row denotes statistically significant differences $(P<0.05)$ 
particularly large for various AAs (Wu et al. 2014). The whole-body AA composition of fish is shown in Table 5. Fish fed the PF diet had the highest and lowest whole-body arginine and threonine levels, respectively $(P<0.05)$. The lowest whole-body threonine in fish fed PF diet might be linked to the lowest survival rate in this group. In this regard, Yaghoubi et al. (2017) reported that S. hasta fed threonine-deficient diet had the lowest survival rate than fish fed other EAA-deficient diets. It has been reported that threonine is involved in many physiological and biochemical processes, including somatic growth, feed efficiency, digestive and absorptive processes, gene expression regulation, antioxidant and immune functions in different fish species (Gao et al. 2014, Habte-Tsion et al. 2015). In addition, whole-body aspartate, glutamate, and serine in fish fed the PF diet were lower than in other groups. Non-essential AAs can be synthesized de novo in adequate amounts by the animal organism from EAAs to meet the requirements for maintenance, growth, development and health ( $\mathrm{Wu}$ et al. 2013). Thus, in the present study, dietary deficiencies in EAA may have led to the reduction of NEAA in fish fed the PF diet. Other whole-body AAs were not affected by dietary treatments $(P>0.05)$.

Plasma biochemical parameters

In the present study, plasma total protein and albumin were significantly reduced in the EAAD and PF groups in comparison with the control, suggesting a malfunctioning of the liver in these groups (Table 6), since all the plasma proteins with the exception of immunoglobulins are synthesized in this organ (Rosalki and Mcintyre 1999). The results of this study showed that fish fed the EAAD and PF diets had the higher plasma glucose levels than the control group, results that might be attributed to a chronic stress condition in these groups (Barcellos et al. 1999, 2009). The highest plasma glucose in the PF group may have also been attributed to the high levels of carbohydrates in the PF diet as a consequence of limited ability of metabolizing glucose in most

Table 5 Amino acid profile of whole body (\% of amino acids) of $S$. hasta juvenile fed control, essential amino acid deficient (EAAD), and protein-free (PF) diets (mean $\pm \mathrm{SE}, n=3$ )

\begin{tabular}{|c|c|c|c|c|}
\hline & \multicolumn{4}{|l|}{ Diets } \\
\hline & Initial & Control & EAAD & $\mathrm{PF}$ \\
\hline \multicolumn{5}{|c|}{ Essential amino acid } \\
\hline Arginine & $6.4 \pm 0.0$ & $6.7 \pm 0.0^{\mathrm{b}}$ & $6.8 \pm 0.1^{\mathrm{b}}$ & $7.6 \pm 0.1^{\mathrm{a}}$ \\
\hline Histidine & $0.7 \pm 0.0$ & $0.6 \pm 0.0$ & $0.6 \pm 0.0$ & $0.7 \pm 0.0$ \\
\hline Isoleusine & $6.3 \pm 0.0$ & $6.6 \pm 0.2$ & $6.5 \pm 0.1$ & $6.7 \pm 0.1$ \\
\hline Leucine & $7.5 \pm 0.0$ & $7.3 \pm 0.2$ & $7.6 \pm 0.1$ & $7.8 \pm 0.4$ \\
\hline Lysine & $1.4 \pm 0.1$ & $1.1 \pm 0.0$ & $1.2 \pm 0.0$ & $1.4 \pm 0.1$ \\
\hline Methionine & $2.8 \pm 0.0$ & $2.9 \pm 0.1$ & $2.8 \pm 0.0$ & $3.1 \pm 0.1$ \\
\hline Phenylalanine & $2.9 \pm 0.0$ & $3.0 \pm 0.0$ & $2.9 \pm 0.0$ & $3.0 \pm 0.1$ \\
\hline Threonine & $6.7 \pm 0.1$ & $6.8 \pm 0.1^{\mathrm{a}}$ & $7.2 \pm 0.2^{\mathrm{a}}$ & $4.7 \pm 0.5^{\mathrm{b}}$ \\
\hline Valine & $7.7 \pm 0.0$ & $8.1 \pm 0.2$ & $8.1 \pm 0.2$ & $8.4 \pm 0.2$ \\
\hline \multicolumn{5}{|c|}{ Non-essential amino acid composition } \\
\hline Aspartate & $10.9 \pm 0.4$ & $10.2 \pm 0.0^{\mathrm{a}}$ & $10.2 \pm 0.3^{\mathrm{a}}$ & $9.3 \pm 0.4^{\mathrm{b}}$ \\
\hline Glutamate & $18.1 \pm 0.43$ & $17.5 \pm 0.2^{\mathrm{a}}$ & $17.2 \pm 0.1^{\mathrm{a}}$ & $16.0 \pm 0.2^{\mathrm{b}}$ \\
\hline Serine & $6.9 \pm 0.1$ & $7.4 \pm 0.2^{\mathrm{a}}$ & $7.3 \pm 0.1^{\mathrm{a}}$ & $6.5 \pm 0.2^{\mathrm{b}}$ \\
\hline Glycine & $8.3 \pm 0.7$ & $9.0 \pm 0.7$ & $9.6 \pm 0.1$ & $11.6 \pm 1.7$ \\
\hline Taurine & $2.1 \pm 0.1$ & $1.7 \pm 0.1$ & $1.6 \pm 0.0$ & $1.7 \pm 0.1$ \\
\hline Alanine & $7.0 \pm 0.1$ & $7.7 \pm 0.1$ & $7.4 \pm 0.0$ & $7.7 \pm 0.1$ \\
\hline Tyrosine & $2.0 \pm 0.0$ & $2.0 \pm 0.0$ & $2.0 \pm 0.0$ & $2.1 \pm 0.1$ \\
\hline Total EAA & $42.3 \pm 0.0$ & $43.1 \pm 0.6$ & $41.7 \pm 0.5$ & $43.4 \pm 0.4$ \\
\hline Total NEAA & $55.2 \pm 0.1$ & $55.5 \pm 0.7$ & $57.4 \pm 0.6$ & $54.9 \pm 0.2$ \\
\hline Total AA & $97.5 \pm 0.0$ & $98.6 \pm 0.1$ & $99.1 \pm 0.1$ & $98.3 \pm 0.5$ \\
\hline
\end{tabular}

A different superscript in the same row denotes statistically significant differences $(P<0.05)$ 
carnivorous fish species (Booth et al. 2013). On the other hand, the increase in plasma glucose in fish fed the EAAD and PF diets was associated with an increase in plasma creatinine. Creatinine is a waste product from muscle turnover and its plasmatic levels provide an accurate marker of the hepatic and renal function. In one side, the increase in plasma creatinine level indicated a high muscular AA catabolism for gluconeogenesis, which might have resulted in higher plasma glucose levels in fish fed the PF and EAAD diets.

Digestive enzyme activities

Fish growth is mainly associated with its digestive ability that correlates with digestive enzyme activity (Rønnestad et al. 2007). The specific activity of selected pancreatic digestive enzymes in S. hasta juveniles fed different diets is presented in Table 7. Trypsin, non-specific lipase, $\alpha$-amylase, and carboxypeptidase A activities were highest in fish fed the control diet, whereas the lowest activity levels were found in fish fed the PF diet. The activities of trypsin and carboxypeptidase A in fish fed the control diet were 10 and 30 times higher than in fish fed the EAAD and PF diets, respectively. Moreover, the activity of non-specific lipase in fish fed the EAAD and PF diets was ca. four times lower than fish fed the control diet. Regarding $\alpha$-amylase activity, fish fed the control diet had 14 and 35 times higher $\alpha$-amylase activity than fish fed the EAAD and PF diets, respectively $(P<0.05)$. Amino acids have a main role in digestive function through chemical sensing via the $\mathrm{G}$ protein-coupled receptors in the gastrointestinal tract and possibly in other tissues (i.e., liver and brain), gastrointestinal emptying, as potent stimulators of hormone (i.e, cholecystokinin), and pancreatic enzymes secretion, and they (glycine and taurine) conjugate with bile salts, which emulsify diet fats. In addition, AAs modulate growth and metabolism, and regulate intestinal microbiota (Wu et al. 2013, 2014). For instance, glutamic and aspartic acids are major metabolic fuels for intestine to maintain its digestive function and protect the mucosal integrity (Wu et al. 2013). The lowest digestive enzyme activities in fish fed the PF diet supported the above-mentioned results. Furthermore, enzyme secretion closely relates to the development of the pancreas and several studies reported that various EAA can affect the development and structural integrity of pancreas in fish (Chen et al. 2012, Tang et al. 2013, Li et al. 2015). The results of this study showed that drastic malfunction of exocrine pancreas may as a consequence of disorders in the abovementioned mechanisms.

\section{Conclusion}

The results of this study showed that dietary protein and EAA deficiencies had negative effects on metabolic and physiological responses in $S$. hasta juveniles. The lack of dietary AAs for the protein synthesis led to lower survival and growth rates in fish fed the NEAA and PF diets. In addition, drastic changes in plasma metabolite parameters including protein, albumin, glucose, and creatinine indicated disorders in the liver and kidney function, as well in the metabolic pathways of fish fed NEAA and PF diets. Digestive enzyme secretion was lower in the NEAA and PF groups, indicating a main role of AAs in the synthesis and secretion of these enzymes from the exocrine pancreas in fish. The results of the current study may serve as a basis for establishing the optimal nitrogen content with proper AAs profile in the diet for $S$. hasta and other sparid species, to increase fish productivity while preventing $\mathrm{N}$ waste and environmental damage. However, more

Table 6 Plasma biochemical parameters of $S$. hasta juvenile fed control, essential amino acid deficient (EAAD), and protein-free (PF) diets (mean $\pm \mathrm{SE}, n=3$ )

\begin{tabular}{lrrr}
\hline & \multicolumn{2}{c}{ Dietary treatments } & \\
\cline { 2 - 3 } & \multicolumn{1}{c}{ Control } & EAAD & PF \\
\hline Total Protein $\left(\mathrm{g} \mathrm{l}^{-1}\right)$ & $29.0 \pm 3.0^{\mathrm{a}}$ & $4.3 \pm 0.2^{\mathrm{b}}$ & $2.8 \pm 0.1^{\mathrm{c}}$ \\
Albumin $\left(\mathrm{g} \mathrm{dl}^{-1}\right)$ & $19.6 \pm 0.1^{\mathrm{a}}$ & $0.3 \pm 0.0^{\mathrm{b}}$ & $0.2 \pm 0.0^{\mathrm{b}}$ \\
Glucose $\left(\mathrm{mg} \mathrm{dl}^{-1}\right)$ & $134.0 \pm 7.0^{\mathrm{c}}$ & $145.2 \pm 8.0^{\mathrm{b}}$ & $231.6 \pm 14.0^{\mathrm{a}}$ \\
Creatinine $\left(\mathrm{mg} \mathrm{dl}^{-1}\right)$ & $2.1 \pm 0.1^{\mathrm{c}}$ & $10.8 \pm 0.6^{\mathrm{b}}$ & $23.4 \pm 1.1^{\mathrm{a}}$ \\
\hline
\end{tabular}

A different superscript in the same row denotes statistically significant differences $(P<0.05)$ 
Table 7 Pancreatic digestive enzyme activities (U mg protein ${ }^{-1}$ ) of $S$. hasta juvenile fed control, essential amino acid deficient (EAAD), and protein-free (PF) diets (mean $\pm \mathrm{SE}, n=3$ )

\begin{tabular}{llrr}
\hline & \multicolumn{2}{l}{ Diets } & \\
\cline { 2 - 4 } & Control & EAAD & PF \\
\hline Trypsin & $3.1 \pm 0.5^{\mathrm{a}}$ & $0.3 \pm 0.2^{\mathrm{b}}$ & $0.1 \pm 0.0^{\mathrm{c}}$ \\
Lipase & $2.2 \pm 0.1^{\mathrm{a}}$ & $0.6 \pm 0.1^{\mathrm{b}}$ & $0.5 \pm 0.0^{\mathrm{b}}$ \\
$\alpha$-Amylase & $1.4 \pm 0.0^{\mathrm{a}}$ & $0.1 \pm 0.0^{\mathrm{b}}$ & $0.04 \pm 0.0^{\mathrm{c}}$ \\
Carboxypeptidase A & $3.0 \pm 0.4^{\mathrm{a}}$ & $0.3 \pm 0.0^{\mathrm{b}}$ & $0.1 \pm 0.0^{\mathrm{c}}$ \\
\hline
\end{tabular}

A different superscript in the same row denotes statistically significant differences $(P<0.05)$

work is needed to evaluate the effects of dietary protein levels and AA profile on the utilization efficiency of limiting AAs, as well as to determine the influence of the duration of the experiments or fish size on their EAA requirements for maintenance.

Acknowledgements This article is extracted from the project recorded under code number of 92011610 and financially supported by Iran National Science Foundation. We are grateful to the director and staff of the Mariculture Research Station, Sarbandar, Iran for providing the necessary facilities for the experiment.

Author contributions MTM: Conducting the feeding trial, sampling and lab works. MY: Helping in lab works. JGM: Feed furmulation. OS: Supervising all experimental analyses and statistics. EG: Help in manuscript preparation.

\section{Compliance with ethical standards}

Conflict of interest There is no conflict of interest between authors in the publication of this paper.

Open Access This article is distributed under the terms of the Creative Commons Attribution 4.0 International License (http:// creativecommons.org/licenses/by/4.0/), which permits unrestricted use, distribution, and reproduction in any medium, provided you give appropriate credit to the original author(s) and the source, provide a link to the Creative Commons license, and indicate if changes were made.

\section{References}

Abboudi T, Mambrini M, Ooghe W, Larondelle Y, Rollin X (2006) Protein and lysine requirements for maintenance and for tissue accretion in Atlantic salmon (Salmo salar) fry. Aquaculture 261:369-383

Abboudi T, Mambrini M, Larondelle Y, Rollin X (2009) The effect of dispensable amino acids on nitrogen and amino acid losses in Atlantic salmon (Salmo salar) fry fed a protein-free diet. Aquaculture 289:327-333

Anthony TG, Reiter AK, Anthony JC, Kimball SR, Jefferson LS (2001) Deficiency of dietary EAA preferentially inhibits mRNA translation of ribosomal proteins in liver of meal-fed rats. Am J Physiol Endocrinol Metabol 281:430-439

AOAC (2005) Official methods of analysis of association of official analytical chemists. Association of Official Analytical Chemists, Gaithersburg

Barcellos L, Nicolaiewsky S, De Souza S, Lulhier F (1999) Plasmatic levels of cortisol in the response to acute stress in Nile tilapia, Oreochromis niloticus(L.), previously exposed to chronic stress. Aquac Res 30:437-444

Barcellos LJG, Kreutz LC, Quevedo RM, da Rosa JGS, Koakoski G, Centenaro L, Pottker E (2009) Influence of color background and shelter availability on jundiá (Rhamdia quelen) stress response. Aquaculture 288:51-56

Booth MA, Moses MD, Allan GL (2013) Utilisation of carbohydrate by yellowtail kingfish Seriola lalandi. Aquac 376-379:151-161

Bradford MM (1976) A rapid and sensitive method for the quantitation of microgram quantities of protein utilizing the principle of protein-dye binding. Anal Biochem 72:248-254

Chen G, Feng L, Kuang S, Liu Y, Jiang J, Hu K, Jiang W, Li S, Tang L, Zhou X (2012) Effect of dietary arginine on growth, intestinal enzyme activities and gene expression in muscle, hepatopancreas and intestine of juvenile Jian carp (Cyprinus carpio var. Jian). Br J Nutr 108:195-207

Erlanger BF, Kokowsky N, Cohen W (1961) The preparation and properties of two new chromogenic substrates of trypsin. Arc Biochem Biophys 95:271-278

Folk J, Schirmer E (1963) The porcine pancreatic carboxypeptidase A system I. Three forms of the active enzyme. J Biol Chem 238:3884-3894

Gao YJ, Yang HJ, Liu YJ, Chen SJ, Guo DQ, Yu YY, Tian LX (2014) Effects of graded levels of threonine on growth performance, biochemical parameters and intestine morphology of juvenile grass carp Ctenopharyngodon idella. Aquaculture 424:113-119 
Gawlicka A, Parent B, Horn MH, Ross N, Opstad I, Torrissen OJ (2000) Activity of digestive enzymes in yolk-sac larvae of Atlantic halibut (Hippoglossus hippoglossus): indication of readiness for first feeding. Aquaculture 184:303-314

Gisbert E, Giménez G, Fernández I, Kotzamanis Y, Estévez A (2009) Development of digestive enzymes in common dentex Dentex dentex during early ontogeny. Aquaculture 287:381-387

Habte-Tsion HM, Ge X, Liu B, Xie J, Ren M, Zhou Q, Miao L, Pan L, Chen R (2015) A deficiency or an excess of dietary threonine level affects weight gain, enzyme activity, immune response and immune-related gene expression in juvenile blunt snout bream (Megalobrama amblycephala). Fish Shellfish Immunol 42:439-446

Kaushik S, Doudet T, Médale F, Aguirre P, Blanc D (1995) Protein and energy needs for maintenance and growth of Nile tilapia (Oreochromis niloticus). J App Ichthyol 11:290-296

Li W, Feng L, Liu Y, Jiang WD, Kuang SY, Jiang J, Li SH, Tang L, Zhou XQ (2015) Effects of dietary phenylalanine on growth, digestive and brush border enzyme activities and antioxidant capacity in the hepatopancreas and intestine of young grass carp (Ctenopharyngodon idella). Aquacult Nutr 21:913-925

Lindroth P, Mopper K (1979) High performance liquid chromatographic determination of subpicomole amounts of amino acids by precolumn fluorescence derivatization with o-phthaldialdehyde. Anal Chem 51:1667-1674

Marammazi JG, Yaghoubi M, Safari O, Peres H, Mozanzadeh MT (2017) Establishing the optimum dietary essential amino acids pattern for silvery-black porgy (Sparidentex hasta) juveniles by deletion method. Aquacult Nutr 00:1-9

Mozanzadeh MT, Marammazi JG, Yaghoubi M, Agh N, Pagheh E, Gisbert E (2017) Macronutrient requirements of silvery-black porgy (Sparidentex hasta): a comparison with other farmed Sparid species. Fishes 2(2):5

NRC (2011) Nutrient Requirements of Fish and Shrimp. The National Academic Press, Washington, D.C.

Peres H, Oliva-Teles A (2006) Effect of the dietary essential to non-essential amino acid ratio on growth, feed utilization and nitrogen metabolism of European sea bass (Dicentrarchus labrax). Aquaculture 256:395-402

Rønnestad I, Kamisaka Y, Conceição L, Morais S, Tonheim S (2007) Digestive physiology of marine fish larvae: hormonal control and processing capacity for proteins, peptides and amino acids. Aquaculture 268:82-97

Rosalki S, Mcintyre NI (1999) Biochemical investigations in the management of liver disease. Oxf Text Clin Hepatol 2:503-521

Solovyev M, Gisbert E (2016) Influence of time, storage temperature and freeze/thaw cycles on the activity of digestive enzymes from gilthead sea bream (Sparus aurata). Fish Physiol Biochem 42:1383-1394

Tang L, Wang GX, Jiang J, Feng L, Yang L, Li SH, Kuang SY, Zhou XQ (2009) Effect of methionine on intestinal enzymes activities, microflora and humoral immune of juvenile Jian carp (Cyprinus carpio var. Jian). Aquacult Nutr 15:477-483

Tang L, Feng L, Sun CY, Chen GF, Jiang WD, Hu K, Liu Y, Jiang J, Li SH, Kuang SY (2013) Effect of tryptophan on growth, intestinal enzyme activities and TOR gene expression in juvenile Jian carp (Cyprinus carpio var. Jian): studies in vivo and in vitro. Aquaculture 412:23-33

Von der Decken A, Lied E (1993) Metabolic effects on growth and muscle of soya-bean protein feeding in cod (Gadus morhua). Br J Nutr 69:689-697

Wilson RP (2002) Amino Acids and Proteins. In: Hardy JEHW (ed) Fish Nutrition, 3rd edn. Academic Press, San Diego, pp 143-179

Worthington C (1991) Worthington enzyme manual related Biochemical. Freehold, New Jersey

Wu G, Wu Z, Dai Z, Yang Y, Wang W, Liu C, Wang B, Wang J, Yin Y (2013) Dietary requirements of "nutritionally nonessential amino acids" by animals and humans. Amino Acids 44:1107-1113

Wu G, Bazer F, Dai Z, Li D, Wang J, Wu Z (2014) Amino acid nutrition in animals: protein synthesis and beyond. Ann Rev Anim Biosci 2:387-417

Yaghoubi M, Mozanzadeh M, Marammazi J, Safari O, Gisbert E (2017) Effects of dietary essential amino acid deficiencies on the growth performance and humoral immune response in silvery-black porgy (Sparidentex hasta) juveniles. Aquacult Res 00:1-13

\section{Publisher's Note}

Springer Nature remains neutral with regard to jurisdictional claims in published maps and institutional affiliations. 